\title{
PLASMA CALCIUM AND MAGNESIUM CONCENTRATIONS IN PATIENTS WITH FRACTURES OF LONG BONES TREATED SURGICALLY
}

\author{
Maysam Bacher, Ma33orzata Sztanke, \\ Krzysztof Sztanke, Kazimierz Pasternak
}

\author{
Chair and Department of Medical Chemistry \\ Medical University of Lublin
}

\begin{abstract}
Bone fractures, especially when treated surgically, are connected with changes in the homeostasis of the elements of which bone compounds consist, as well as the ones which participate in controlling processes. Such changes influence both the fracture itself and the operative procedure. For successful treatment of broken bones, it can be crucial to bring the homeostasis of bioelements back to the normal state.

Thus, the aim of this work has been to determine magnesium and calcium concentrations in plasma from patients with fractures of long bones, and to analyze changes in the examined elements depending on the time after the operative procedure, injury and patient's age.

The research was conducted on the blood of patients: 1) with long bone fractures treated surgically, 2) after a limb amputation because of a fracture or injury, 3) with long bone fractures and with multiorgan injury. With respect to the patients' age, there were 3 groups: 1) patients aged 18-40 years, 2) patients aged 41-60 years, 3) patients older than 60 years. In the postoperative period, the patients were on a strict postoperative diet, receiving only i.v. $0.9 \% \mathrm{NaCl}$ and $5 \%$ glucose solutions.

Blood was taken from patients first directly after admittance to hospital and next on the first, third, fifth and seventh day after an operative procedure.

Plasma calcium and magnesium concentrations were determined by the method of emission spectrometry with induction plasma (ICP-OES). The results were worked out statistically. The differences $p \varangle 0.05$ were taken into consideration as statistically significant.

The research showed that in the blood plasma from patients with long bone fractures treated surgically, there were noticeable decreases of calcium and magnesium concentra-
\end{abstract}

prof. dr hab. Kazimierz Pasternak, Chair and Department of Medical Chemistry Medical University of Lublin, Staszica 4, 20-081 Lublin, Poland, phone/fax 081 5357361, e-mail: kazimierz.pasternak@umlub.pl 
tions mainly on the first, third and fifth postoperative day. These changes depended on the extend of an operative procedure, but did not depend on the patients' age. However, with respect to magnesium, its statistically significant decrease was noticed in the group of oldest patients.

In the postoperative period, it is especially important to pay attention to calcium and magnesium concentrations, and for patients over 60 years of age magnesium supplementation is necessary. Maintenance of macronutrient homeostasis in an organism can be crucial for the patient's convalescence process.

Key words: calcium, magnesium, long bone's fractures, surgical treatment.

\title{
OSOCZOWE STÊ' ${ }^{-}$ENIA WAPNIA I MAGNEZU U PACJ ENTÓW ZE ZfAMANIAMI KOCEI DEUGICH LECZONYCH OPERACYJ NIE
}

\begin{abstract}
Abstrakt
$Z^{3} a m a n i a$ koœei, szczególnie leczone operacyjnie, $w^{1}{ }^{1}{ }^{1}$ siê ze zmianami homeostazy pierwiastków wchodz ${ }^{1}$ cych $w$ sk $^{3}$ ad zwi $^{1}$ zków buduj ${ }^{1}$ cych koœei, a tak ¿e bior ${ }^{1}$ cych udzia ${ }^{3}$ w procesach regulacyjnych. Wp3ywa na to zarówno samo $z^{3} a m a n i e$, jak i zabieg operacyjny. Normalizacja zaburzeñ w homeostazie biopierwiastków moje mieæistotne znaczenie dla zrostu koøei w procesie zdrowienia pacjenta ze $z^{3} a m a n i e m$.

Celem pracy by ${ }^{3} 0$ oznaczenie stê¿eñ magnezu i wapnia w osoczu krwi pacjentów hospitalizowanych $z$ powodu $z^{3}$ amañ koœi dugich oraz analiza tych zmian $w$ zalęnoœi od czasu po zabiegu operacyjnego leczenia $z^{3} a m a n i a$, rozleg3oøei urazu oraz wieku pacjenta.

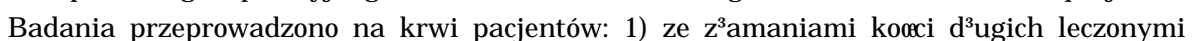
operacyjnie, 2) u których z powodu $z^{3} a m a n ̃ ~ i ~ u r a z u ~ k o n i e c z n a ~ b y{ }^{3} a$ amputacja koñczyny, 3) ze $z^{3} a m a n i a m i ~ k o ø e i ~ d^{3} u g i c h, k t o ́ r y m ~ t o w a r z y s z y^{3}$ du¿y uraz wielonarz ${ }^{1}$ dowy. Ze wzglêdu

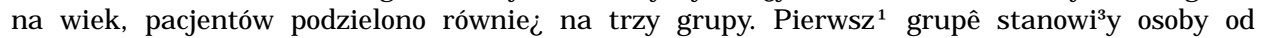
18. do 40. roku ¿ycia, drug ${ }^{1}$ - od 41. do 60. roku ¿ycia, trzeci ${ }^{1}$ - powyiej 60. roku ¿ycia.

Od pacjentów pobierano krew bezpoceednio po przyjêciu do szpitala oraz w 1., 3., 5. i 7. dobie po zabiegu operacyjnym.

Oznaczenia stêeieñ pierwiastków w osoczu krwi wykonano metod ${ }^{1}$ optycznej spektrometrii emisyjnej $z$ plazm ${ }^{1}$ indukcyjnie wzbudzon ${ }^{1}$ (ICP-OES). Wyniki poddano analizie statystycznej. Za statystycznie istotne uznano ró¿nice w przypadku $p<0,05$.

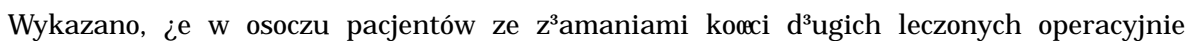
stwierdzono zmniejszenie stêieñ wapnia i magnezu gónnie w 1., 3. i 5 . dobie pooperacyjnej. Zmiany te zale ¿a $a^{3} y$ od rozleg ${ }^{3}$ oœi zabiegu operacyjnego, a nie by ${ }^{3} y$ zale ¿ne od wieku. J ednak w przypadku magnezu zaobserwowano statystycznie istotne zmniejszenie jego stê ¿enia w grupie najstarszych pacjentów.

W okresie pooperacyjnym wskazane jest szczególne zwrócenie uwagi na stêienia wapnia i magnezu, a u pacjentów powy¿ej 60 . roku ¿ycia konieczna jest suplementacja magnezu. Zapewnienie homeostazy makropierwiastków w organizmie moje mieæwp³yw na proces zdrowienia pacjenta.
\end{abstract}

$S^{3}$ owa kluczowe: wapñ, magnez, $z^{3} a m a n i a$ koøi $d^{3} u g i c h$, leczenie operacyjne. 


\section{INTRODUCTION}

Calcium makes up just $1.4-1.6 \%$ of body mass and it is mainly accumulated in the skeleton (99\%). The remaining $1 \%$ of this element is in the blood plasma in three forms: in an ionized form - about $48 \%$, bonded with proteins - 46\%, in complexes with citrates and phosphates - $6 \%$. Calcium salts are components of the skeleton and teeth, ensuring their proper resistance and hardness. It is calcium that many enzyme activity, muscle functions, humoural stimulus transmission, proper heart action, blood coagulability and iron absorption in organism depend on (BENECH et al. 1998). Calcium is also an important component of cellular and intracellular membranes, which conditions their permeability. In order to provide adequate amounts and availability of calcium ions, an organism maintains the proper homeostasis, both at the cellular and systemic levels. Calcium deficiencies and disturbances in hormonal secretion processes, directly interfering with homeostasis of this element, are the causes for different pathologic syndromes. The main regulators of calcaemia are parathormone, vitamin D and calcitonin. Parathormone, which is synthesized by parathyroid glands, increases calcium release and its renal reabsorption, and it probably also enhances intestinal absorption of this element. Calcitonin decreases calcium release from the skeleton and increases its release by kidneys. Calcium stimulates the secretion of calcitonin. Active metabolites of vitamin D, especially 1,25-dihydroxycholecalciferol, increase intestinal absorption of calcium and its renal resorption (Кокот 2001, LePAGE et al. 1998, Otтo-BuczKowsKA 2002). According to ZdRoj EWICZ and BeLowsKA-Bieñ (2003), it is also a calcic receptor (CaR), which belongs to group $C$ of receptors connected with protein $G$ that plays an important role in the process of calcium homeostasis maintenance. This receptor is mainly situated on the surface of parathyroid glands, kidneys, intestines, bones and thyroid C cells, but also in tissues that are not connected with calcium metabolism, such as skin, the brain and the pancre as. Calcium receptor mutations are the reason for the whole family of existing disorders in calcium metabolism.

Main symptoms of reduced calcium concentration in blood, i.e. hypocalcaemia, are arrhythmia, intensified muscular excitability, anxiety, vertigo and stomachache. In the case of a prolonged calcium deficiency in an organism, processes intensifying its release from bones begin. If such a state lasts for a long time, then mechanical bone resistance decreases and bone decalcification is initiated. As a consequence, bones lose their resistance to injuries and the risk of fractures increases due to weaker bone structure and progressing osteoporosis. Prolonged calcium deficit can also cause dental caries, rickets and disorders in many other Processes (Allgrove 2003, J AKUBAS-KWIATKOWSKA et al. 2005, TAKAMI, IKI 2005).

Magnesium also plays an important role in human physiology. It participates in many metabolic, regulatory and structural functions. Nowadays, 
it is claimed that this element plays a role as a cofactor of over three-hundred enzymes involved in biochemical reactions connected with storage and usage of energy, carbohydrate catabolism, protein and fat synthesis, membrane transport of sodium, potassium and calcium, proper nerve conduction and efficient functions of muscles, especially the cardiac muscle (AL GHAMDI et al. 1994, Droesti 1995, 1991, MarcinKowska-Suchowierska 1991, PapierkowsKI 2002).

Magnesium is also an element which is necessary for life. It is the second cation as regards the amount in a cell, and the fourth with respect to the amount in a whole organism (PAsternak 2000, Takami, Shinnichi 2005). There is about $1,000 \mathrm{mmol}$ of magnesium in an adult human organism, out of which about $50-60 \%$ is found in bones. Next to calcium, magnesium is the main mineral component which is necessary for the proper formation of the skeletal structure (FormanowICZ, FormanowICZ 2004, foNIEWSKI 2003). On a cellular level, magnesium acts as an activator of many enzymes (NoronHA, Matuschak 2002, Pasternak 2000, Saris 2000, Wolf, CitTAdini 2003).

Magnesium homeostasis is supported by the state of balance in processes of supply, absorption, use and excretion of this element. The proper magnesium concentration in the plasma ranges from 0.7 to $1.2 \mathrm{mmol} \mathrm{dm}^{-3}$ (Noronha, MAtuschaK 2002), and owing to magnesium release from tissues, mainly bones, it is possible to keep it at this level even during high $\mathrm{Mg}$ deficiency. Thus, changes in magnesium concentration in the plasma do not inform us about its reserve in tissues, but can indicate magnesium metabolism (Marcinkowska-Suchowierska 1991, Noronha, Ogoñski et al. 1997). Among clinical consequences of disturbed magnesium homeostasis, we can name arrhythmia and neurological disorders, both of which can cause higher mortality (Allgrove 2003, J ohnson 2001, Kozielec, Starobrat-Hemerlin 1998, PASTERNAK 2000). Hypomagnesaemia is most often caused by reduced magnesium supply with food, excessive excretion in urine, disturbances in its absorption in the alimentary tract and disorders in the distribution of this element in an organism. Clinical observations show that hypocalcaemia quite often accompanies hypomagnesaemia (OTTo-Buczkowska 2002).

Magnesium deficiency in an organism causes loss of muscular strength and inferior neuromuscular transmission, which leads to inferior movement coordination and a higher risk of a fall, which can be the main reason for bone fractures, especially fractures of forearm bones and the femoral bone. The risk of a fracture for women aged over 50 years is 39\% (CZERWIÑSKI, Borowy 2006). Insufficient magnesium supply to a human organism has been pointed recently as one of the risk factor for osteoporosis (GRAJ ETA 2003, KoRKosz 2003, TAKAMI, IKI 2005). There are some mechanisms implied as responsible for depressing the skeletal mass when there is lack of magnesium in an organism. These are mainly mechanisms stimulated by nutrition and environmental conditions. Some research conducted on animals showed that magnesium deficiency causes inhibition of bone growth, acceleration 
of bone tissue resorption, decrease in bone capacity and increase in bone fragility (KoRKosz 2003, SKIBNIEWSKA et al. 1999).

Most elements in blood, especially calcium and magnesium ions, highly influence bone tissue metabolism. Bone is the kind of tissue where many metabolic processes continually occur. It is a live tissue, constantly changing into new one during reconstruction processes, which simultaneously take part in different places of the skeletal system (GALus 1994).

The skeletal system vulnerable to fractures, which are most often connected with injuries and the health state of this system. The extent of an injury, direction of the applied force and type of a bone are crucial for the type and extent of a resulting fracture. The structure of bones and the degree of bone saturation with both organic and inorganic compounds are an important factor that influences each bone's vulnerability and, at the same time, conditions its resistance. Bone fractures, especially the ones treated surgically, are connected with changes in the homeostasis of elements of which bone compounds consist as well as the ones which participate in controlling processes. Such changes influence both the fracture itself and the operative procedure. For successful treatment of broken bones, it can be crucial to bring the homeostasis of bioelements back to the normal state. Thus, the aim of this work has been to determine magnesium and calcium concentrations in the plasma from patients with long bone fractures and to analyze changes in the examined elements depending on the time after an operative procedure, extent of an injury and the patient's age.

\section{MATERIAL AND METHODS}

The research was conducted on blood samples taken from patients treated surgically because of long bone fractures in the Surgery Clinic of the Independent Public Clinical Hospital Nol in Lublin and in a hospital in Ryki. The research was conducted with the consent of the Ethics Board of the Medical Academy in Lublin (consent no KE-0254/102/2006).

The group of patients consisted of 51 people, 30 men and 21 women, of the average age $51.7+17.9$ years. The patients were divided into 3 groups. The first group consisted of patients with long bone fractures treated surgically (34 patients); the second one of patients who had a limb amputated because of a fracture or injury ( 6 patients) and the third group comprised patients with long bone fractures and with multiorgan injury (11 patients). With respect of the patients' age, there were 3 groups distinguished from the research group: patients aged 18-40 years, aged 41-60 years and patients older than 60 years. In the postoperative period (two days), patients were on a strict postoperative diet, during which they only received intravenously $0.9 \% \mathrm{NaCl}$ solution and $5 \%$ glucose solution. However, they did not receive 
any infusion solutions, which could have influenced magnesium and calcium concentrations.

Blood was taken from patients' elbow vein directly after admittance to hospital and then on the first, third, fifth and seventh day after an operative procedure. The blood was sampled directly to heparinized test tubes. Next, the sampled blood was centrifuged for 15 minutes, at the revolution of $3000 x g$, in a MPW type centrifuge. The plasma was separated and frozen at -20 o C until the determinations.

Concentrations of the elements in the plasma were determined by emission spectrometry with induction plasma (ICP-OES), using a Liberty II model sequence spectrometer made by Varian Company. In this method, determination of a particular element was based on the measurement of the intensity of radiation emitted at a wavelength characteristic for a given ele ment. For determination of calcium concentration the length $315.887 \mathrm{~nm}$ was applied, and for magnesium concentration the length $279.083 \mathrm{~nm}$ was used. The spectrometer was calibrated using multielement patterns by MERCK Company.

The results were worked out statistically with Medistat 2.0 version programme. The results were analysed by t-Student test, and the comparison of groups of results was done on the basis of Cochran-Cox test. The differences $p<0.05$ were taken into consideration as statistically significant.

\section{RESULTS AND DISCUSSION}

Magesium and calcium concentrations in the tested groups of patients are presented in Figures 1-2 and Tables 1-3.

Plasma calcium and magnesium concentrations in patients with long bones' fractures are presented in Table 1.

The average calcium concentration in the analyzed postoperative periods did not differ from its concentration determined on admittance to hospital.

Similarly, magnesium concentration, although decreasing in the postoperative period (on the first, third and fifth day), did not show any statistically significant differences in comparison to its concentration determined on admittance to hospital.

The plasma calcium and magnesium concentrations in patients with long bone fractures who had a limb amputated are presented in Table 2.

In the analyzed patient group, the average calcium concentration fluctuated from 2.20 to $2.50 \mathrm{mmol} \mathrm{dm}^{-3}$. The changes in the concentration of this element on the consecutive postoperative days were not statistically significant versus the concentration determined on admittance to hospital. 


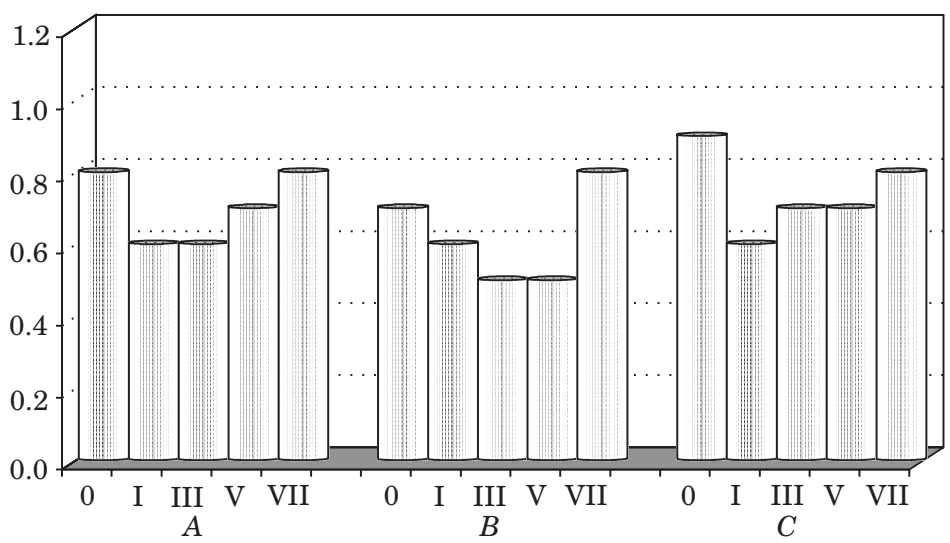

Fig. 1. Magesium concentrations $\left(\mathrm{mmol} \cdot \mathrm{dm}^{-3}\right)$ in tested groups of patients: $\mathrm{A}$ - patients with long bone fractures, B - patients with long bone fractures and limb amputation,

C - patients with long bone fractures with extensive soft tissue injuries

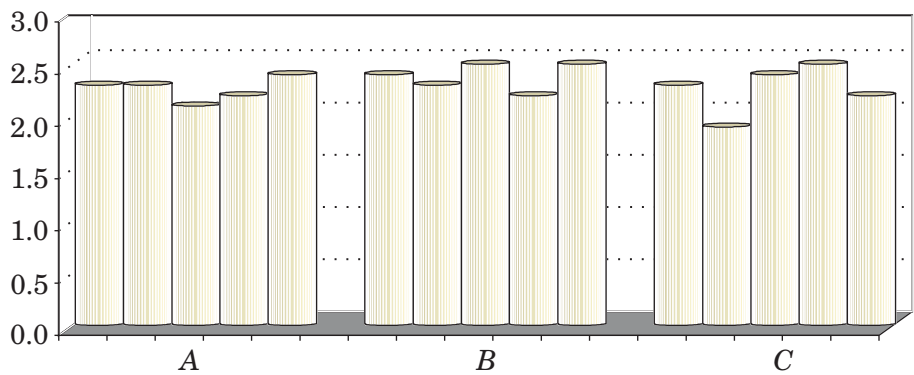

Fig. 2. Calcium concentrations $\left(\mathrm{mmol} \cdot \mathrm{dm}^{-3}\right)$ in tested groups of patients: $A$ - patients with long bone fractures, B - patients with long bone fractures and limb amputation, C - patients with long bone fractures with extensive soft tissue injuries

Table 1

Plasma calcium and magnesium concentrations in patients with long bone fractures

\begin{tabular}{|l|c|c|c|c|c|}
\hline \multirow{2}{*}{$\begin{array}{c}\text { Element } \\
\left(\mathrm{mmol} \mathrm{dm}^{-3}\right)\end{array}$} & \multicolumn{5}{|c|}{ Day } \\
\cline { 2 - 6 } & 0 & $\mathrm{I}$ & III & $\mathrm{V}$ & VII \\
\cline { 2 - 6 } & $X \pm \mathrm{SD}$ & $X \pm \mathrm{SD}$ & $X \pm \mathrm{SD}$ & $X \pm \mathrm{SD}$ & $X \pm \mathrm{SD}$ \\
\hline Calcium & $2.30 \pm 0.17$ & $2.30 \pm 0.35$ & $2.10 \pm 0.08 \downarrow$ & $2.20 \pm 0.38 \downarrow$ & $2.40 \pm 0.36 \uparrow$ \\
\hline Magnesium & $0.80 \pm 0.18$ & $0.60 \pm 0.09 \downarrow$ & $0.60 \pm 0.08 \downarrow$ & $0.70 \pm 0.16 \downarrow$ & $0.80 \pm 0.09$ \\
\hline
\end{tabular}

* - difference statistically important in comparison to its concentration on admittance to hospital

$\uparrow$ - increase in comparison to its concentration on admittance to hospital

$\downarrow$-decrease in comparison to its concentration on admittance to hospital 
Plasma calcium and magnesium concentrations in patients with long bones fractures who had a limb amputated

\begin{tabular}{|l|c|c|c|c|c|}
\hline \multirow{2}{*}{$\begin{array}{c}\text { Element } \\
\left(\mathrm{mmol} \mathrm{dm}-{ }^{3}\right)\end{array}$} & \multicolumn{5}{|c|}{ Day } \\
\cline { 2 - 6 } & 0 & $\mathrm{I}$ & $\mathrm{III}$ & $\mathrm{V}$ & VII \\
\cline { 2 - 6 } & $X \pm \mathrm{SD}$ & $X \pm \mathrm{SD}$ & $X \pm \mathrm{SD}$ & $X \pm \mathrm{SD}$ & $X \pm \mathrm{SD}$ \\
\hline Calcium & $2.40 \pm 0.39$ & $2.30 \pm 0.37 \downarrow$ & $2.50 \pm 0.28 \uparrow$ & $2.20 \pm 0.46 \downarrow$ & $2.50 \pm 0.18 \uparrow$ \\
\hline Magnesium & $0.70 \pm 0.16$ & $0.60 \pm 0.08 \downarrow$ & $0.50 \pm 0.07^{*}$ & $0.50 \pm 0.17 \downarrow$ & $0.80 \pm 0.08 \uparrow$ \\
\hline
\end{tabular}

* - difference statistically important in comparison to its concentration on admittance to hospital

$\uparrow$ - increase in comparison to its concentration on admittance to hospital

$\downarrow$-decrease in comparison to its concentration on admittance to hospital

A decrease in the magnesium concentration relative its concentration on admittance to hospital was noticed on the first, on the third and on the fifth postoperative day. The lowest magnesium concentration was noticed on the third postoperative day, which was statistically significant as compared to the concentration of this element on admittance to hospital.

The plasma calcium and magnesium concentrations in patients with long bone fractures with extensive soft tissue injuries are presented in Table 3.

Table 3

Plasma calcium and magnesium concentrations in patients with long bones fractures with extensive soft tissue injuries

\begin{tabular}{|l|c|c|c|c|c|}
\hline \multirow{2}{*}{$\begin{array}{c}\text { Element } \\
(\mathrm{mmol} \mathrm{dm}\end{array}$} & \multicolumn{5}{|c|}{ Day } \\
\cline { 2 - 6 } & 0 & $\mathrm{I}$ & $\mathrm{III}$ & $\mathrm{V}$ & VII \\
\cline { 2 - 6 } & $X \pm \mathrm{SD}$ & $X \pm \mathrm{SD}$ & $X \pm \mathrm{SD}$ & $X \pm \mathrm{SD}$ & $X \pm \mathrm{SD}$ \\
\hline Calcium & $2.30 \pm 0.47$ & $1.90 \pm 0.26 \downarrow$ & $2.40 \pm 0.37 \uparrow$ & $2.50 \pm 0.40 \uparrow$ & $2.20 \pm 0.48 \downarrow$ \\
\hline Magnesium & $0.90 \pm 0.16$ & $0.60 \pm 0.07 \downarrow$ & $0.70 \pm 0.18 \downarrow$ & $0.70 \pm 0.08 \downarrow$ & $0.80 \pm 0.16 \downarrow$ \\
\hline
\end{tabular}

* - difference statistically important in comparison to its concentration on admittance to hospital

$\uparrow$ - increase in comparison to its concentration on admittance to hospital

$\downarrow$-decrease in comparison to its concentration on admittance to hospital

The average calcium concentration fell to the lowest value on the first postoperative day, when it was $1.90 \mathrm{mmol} \mathrm{dm}^{-3}$. The changes in the calcium concentration on each analyzed postoperative day were not statistically significant, as compared to the concentrations determined on admittance to hospital.

Magnesium concentrations were low. The highest concentration of this element was noticed on admittance to hospital; afterwards it continued to 
decline down to $0.60-0.70 \mathrm{mmol}_{\mathrm{dm}^{-3}}$. These changes, however, were not significant in comparison to the magnesium concentration on admittance to hospital.

\section{Calcium and magnesium concentrations for particular age groups are presented in Figures 3-4 and Tables 4-6.}

Table 4

Calcium and magnesium concentrations in the youngest age group (18-40 years)

\begin{tabular}{|l|c|c|c|c|c|}
\hline \multirow{2}{*}{$\begin{array}{c}\text { Element } \\
\left(\mathrm{mmol} \mathrm{dm}^{-3}\right)\end{array}$} & \multicolumn{5}{|c|}{ Day } \\
\cline { 2 - 6 } & 0 & $\mathrm{I}$ & III & $\mathrm{V}$ & VII \\
\cline { 2 - 6 } & $X \pm \mathrm{SD}$ & $X \pm \mathrm{SD}$ & $X_{ \pm} \mathrm{SD}$ & $X \pm \mathrm{SD}$ & $X \pm \mathrm{SD}$ \\
\hline Calcium & $2.30 \pm 0.25$ & $2.10 \pm 0.16 \downarrow$ & $2.00 \pm 0.17^{*} \downarrow$ & $2.20 \pm 0.27 \downarrow$ & $2.20 \pm 0.29 \downarrow$ \\
\hline Magnesium & $0.90 \pm 0.17$ & $0.60 \pm 0.07^{*}$ & $0.70 \pm 0.07 \downarrow$ & $0.70 \pm 0.18 \downarrow$ & $0.70 \pm 0.09 \downarrow$ \\
\hline
\end{tabular}

* - difference statistically important in comparison to its concentration on admittance to hospital

$\uparrow$ - increase in comparison to its concentration on admittance to hospital

$\downarrow$ - decrease in comparison to its concentration on admittance to hospital

Table 5

Calcium and magnesium concentrations in patients at the age from 41 to 60 years

\begin{tabular}{|l|c|c|c|c|c|}
\hline \multirow{2}{*}{$\begin{array}{c}\text { Element } \\
(\mathrm{mmol} \mathrm{dm}\end{array}$} & \multicolumn{5}{|c|}{ Day } \\
\cline { 2 - 6 } & 0 & $\mathrm{I}$ & III & $\mathrm{V}$ & VII \\
\cline { 2 - 6 } & $X \pm \mathrm{SD}$ & $X \pm \mathrm{SD}$ & $X \pm \mathrm{SD}$ & $X \pm \mathrm{SD}$ & $X \pm \mathrm{SD}$ \\
\hline Calcium & $2.30 \pm 0.28$ & $2.10 \pm 0.15 \downarrow$ & $2.00 \pm 0.36 \downarrow$ & $2.40 \pm 0.49 \uparrow$ & $2.40 \pm 0.27 \uparrow$ \\
\hline Magnesium & $1.10 \pm 0.18$ & $0.80 \pm 0.08 \downarrow$ & $0.70 \pm 0.16 \downarrow$ & $0.70 \pm 0.07 \downarrow$ & $0.70 \pm 0.09 \downarrow$ \\
\hline
\end{tabular}

* - difference statistically important in comparison to its concentration on admittance to hospital

$\uparrow$ - increase in comparison to its concentration on admittance to hospital

$\downarrow$-decrease in comparison to its concentration on admittance to hospital

Table 6

The concentrations of calcium and magnesium in the oldest age group (over 60 years)

\begin{tabular}{|l|c|c|c|c|c|}
\hline \multirow{2}{*}{$\begin{array}{c}\text { Element } \\
\left(\mathrm{mmol} \mathrm{dm}^{-3}\right)\end{array}$} & 0 & $\mathrm{I}$ & $\mathrm{III}$ & $\mathrm{V}$ & VII \\
\cline { 2 - 6 } & $X \pm \mathrm{SD}$ & $X \pm \mathrm{SD}$ & $X \pm \mathrm{SD}$ & $X \pm \mathrm{SD}$ & $X \pm \mathrm{SD}$ \\
\hline Calcium & $2.40 \pm 0.51$ & $2.10 \pm 0.38 \downarrow$ & $2.10 \pm 0.29 \downarrow$ & $2.40 \pm 0.28$ & $2.30 \pm 0.37 \downarrow$ \\
\hline Magnesium & $1.00 \pm 0.17$ & $0.60 \pm 0.09^{*}$ & $0.60 \pm 0.07 *$ & $0.70 \pm 0.07^{*}$ & $0.80 \pm 0.16 \downarrow$ \\
\hline
\end{tabular}

* - difference statistically important in comparison to its concentration on admittance to hospital

$\uparrow$ - increase in comparison to its concentration on admittance to hospital

$\downarrow$-decrease in comparison to its concentration on admittance to hospital 


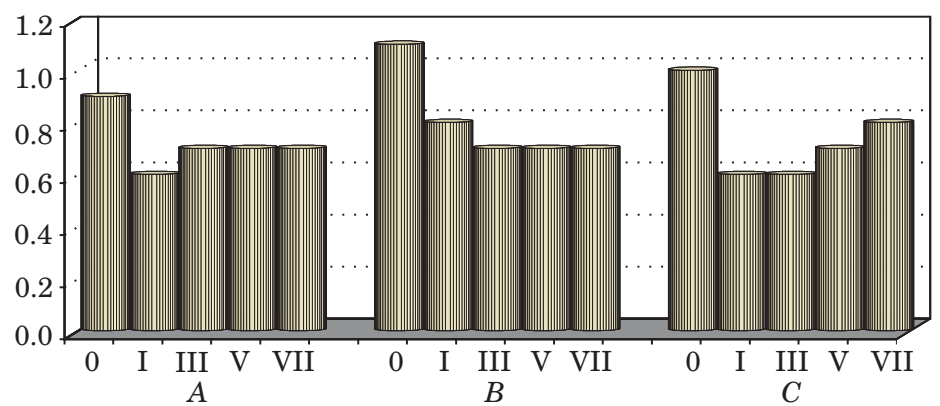

Fig. 3. Magnesium concentrations $\left(\mathrm{mmol} \cdot \mathrm{dm}^{-3}\right)$ for particular age groups of patients: A - patients at the age of 18-40 years, B - patients at the age of 41-60 years,

$\mathrm{C}$ - patients at the age above 60 years

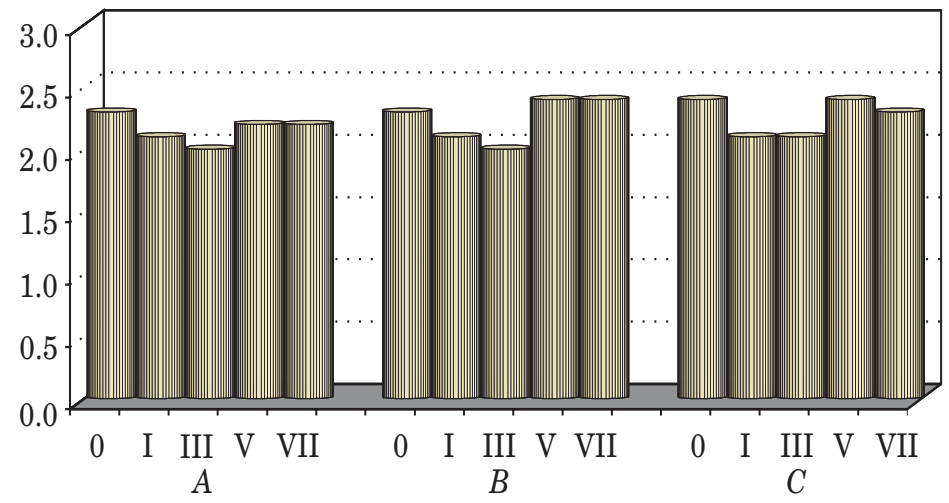

Fig. 4. Calcium concentrations $\left(\mathrm{mmol} \cdot \mathrm{dm}^{-3}\right)$ for particular age groups of patients:

A - patients at the age of 18-40 years, B - patients at the age of 41-60 years,

$\mathrm{C}$ - patients at the age above 60 years

Calcium and magnesium concentrations in the youngest age group (18-40 years) are presented in Table 4.

In the youngest group of patients (18-40 years), a statistically significant decrease, relative to the values determined on admittance to hospital, in the calcium concentration was noticed only on the first postoperative day.

Similarly, the magnesium concentration for this age group showed a very small decreasing tendency. The lowest concentration of this element was noticed on the first postoperative day, and it statistically significant as compared to its concentration on admittance to hospital.

Calcium and magnesium concentrations in patients 41 to 60 years old are presented in Table 5.

In this age group, a decrease in the calcium concentrations was noticed on the first and on the third postoperative day, but these changes were not statistically important as compared to the concentrations determined on admittance to hospital. 
Magnesium concentrations for this age group, in comparison to the initial values, were lower on every postoperative day, but the differences were not statistically significant.

Calcium and magnesium concentrations in the oldest age group (over 60 years) are presented in Table 6.

In the oldest age group, calcium concentrations were the lowest on the first and on the third postoperative day, but the differences were not significant.

In this group, low magnesium concentrations were noticed. On every analyzed postoperative day, the concentrations of this element were lower than on admittance to hospital. On the first, third and fifth postoperative day, these differences were statistically important.

Calcium and magnesium are among the macroelements that play a very important role in both water-electrolyte balance maintenance and cell excitability (Кокот, 2007). Therefore, much attention is paid to their concentration in any clinical research (Кокот 1998, TOMASZEWSKI 2001). Disorders in concentrations of these elements can be caused by many factors, including operative procedures, which are connected with blood loss and systemic fluid depletion.

Magnesium concentration in the blood plasma analyzed on admittance to hospital was quite low, reaching particularly low concentrations in patients whose injuries were so extensive that they had a limb amputated. For these patients, the magnesium concentration was close to the low normal range and fell to the lowest value on the third postoperative day. This decrease was statistically significant as compared both to its concentration on admittance to hospital and to the normal values. Literature data support the results of this analysis, as there are reports on both low contents of magnesium in food (Kozielec, Starobrat-Hemerlin 1998, Kreinhoff et al. 1990, PAPIERKOWSKI 2002) and on its loss in stressful situations (F LORIAÑCZYK 1997, PASTERnAK 2000). Due to the fact that magnesium is an intracellular cation, with only about $1 \%$ of its total content in an organism found extracellularly, the determination of its concentration can be only an indicator of magnesium metabolism. For the sake of maintaining normomagnesaemia, during a decrease in the magnesium concentration in the blood plas$\mathrm{ma}$, the element is released from tissues, mainly from bones, the liver or kidneys, so that hypomagnesaemia appears only when there is high deficiency of magnesium in tissues (PASTERnAK 2000, WALASEK 1998).

Moreover, loss of magnesium connected with a stressful situation, such as a fracture or an operative procedure, is very important for an organism. This claim is supported by other authors (PARTYKA, SITKOWSKA-RYSIAK 2001).

Worth attention is the fact that a statistically significant decrease in the magnesium concentration on the first, third and fifth postoperative day was revealed in the oldest group (over 60 years). It could have been caused by reduced ability to maintain magnesium homeostasis and higher susceptibili- 
ty to stress. The results reported by other authors support the observation that the blood plasma of elderly people contains less magnesium (DURLACH 1991, FLORIAÑCZYK 1997, PASTERNAK 2000).

\section{CONCLUSIONS}

1. In the blood plasma from patients with bone fractures treated surgically, decrease in calcium and magnesium concentrations was determined on the first, third and fifth postoperative day.

2. The concentrations of the analyzed macroelements (calcium, magnesium) in the blood plasma after an operative procedure changed slightly.

3. The changes in the concentration of the macroelements did not depend on the patients' age, although for magnesium, a reduction in its concentration was noticed in the group of the oldest patients (over 60 years).

4. For patients over 60 years of age, magnesium supplementation seems necessary.

\section{REFERENCES}

Al Ghamdi S.M., Cameron E.C., Sutton R.A. 1994. Magnesium deficiency: Pathophysiologic and clinical overviev. Am. J. Kidney Dis., 24: 737-752.

Altgrove J . 2003. Disorders of calcium metabolism. Curr. Pediatr., 13 (7): 529-535.

Benech J .C., Sotelo S., Garcia teijeiro R., Verdes J .M., calliari A., Kun A., Cailliari D., Sotelo J R. 1998. Calcium and cellular metabolism: transport and regulation. Biochem. Education, 26: 228.

CZERWIÑSKı E., Borowy P. 2006. Guidelines of osteoporosis and fall prevention. Terapia, 14 (3): $30-36$.

Droesti I.E. 1995. Magnesium status and health. Nutr. Rev., 53: 23-27.

FLORIAÑCZYK B. 1997. Status magnezu w ustroju i jego niedobory [Magnesium status in an organism and its deficits]. Probl. Lek., 36: 53-58 (in Polish).

Formanowicz D., Formanowicz P. 2004. Magnez - jeden mikroelement, wiele zastosowañ [Magnesium - one micronutrient, many applications]. Crviat Med. Farm., 2: 46-52 (in Polish).

Galus K. 1994. Choroby metaboliczne koœi [Metabolic bone diseases]. Med. Tour Press Int. Wyd. Med., Warszawa (in Polish).

Grajeta H. 2003. Nutrition in prevention and treatment of osteoporosis. Prz. Lek., 60 (10): 649-653.

J akubas-K wiatkowska W., Bfachowicz A., Franke E. 2005. Hipokalcemia w praktyceklinicznej przyczyny, objawy i leczenie [Hypocalcaemia in clinical practice - causes, signs and treatment]. Choroby Serca i Naczyñ, 2 (4): 232-237 (in Polish).

J ohnson S. 2001. The multifaceted and wide spread pathology of magnesium deficiency. Med. Hypotheses, 56: 163-170.

Kokot F., Franke E. 2007. Advances in calcium-phosphorus homeostasis. Post. Nauk Med., 20 (5): 168-174. 
Korkosz M. 2003. Leczenie osteoporozy [Osteoporosis treatment]. Rehabil. Med., 7: 12-19 (in Polish).

Kozielec T., Starobrat-Hemerlin B. 1998. Niedobór magnezu u dzieci nadpobudliwych [Magnesium deficiency in hyperactive children]. Terapia i Leki, 24 (5-6): 158-162 (in Polish).

Kreinhoff U., Elmadfa I., Salomon F., Weidler B. 1990. Antioxidant status after surgical stress. Infusionstherapie, 17 (5): 261-267.

Lepage R., Roy L., Brossard J H., Rousseau L., Dorais C., Lazure C., D'amour P. 1998. A non(I-84)circulating parathyroid hormone (PTH) fragment interferes significantly with intact PTH commercial assay measurements in uremic samples. Clin. Chem., 44: 805-809.

fonIEWSKI I. 2003. Znaczenie magnezu w profilaktyce i leczeniu [Role of magnesium in dise ase prevention and treatment]. Crviat Med. Farm., 30: 32-34 (in Polish).

Marcinkowska-Suchowierska E. 1991. Metabolizm magnezu w zdrowiu i chorobie. Homeostaza magnezu. Czeoæl [Magnesium metabolism in health and illness. Magnesium homeostasis Part I]. Post. Nauk Med., 4: 86-89 (in Polish).

Noronha J.L., Matuschak G.M. 2002. Magnesium in critical illness: metabolism, assessment, and treatment. Int. Care Med., 28: 667-679.

Ogoñskı T., Bohatyrewicz A., Noceñ I., Karpiñska K. 1997. Magnez w koœiach ludzi ze zªmaniem szyjki koœi udowej [Magnesium in bones of patients with a femoral neck fracture]. Biul. Magnezol., 2 (2): 126-129 (in Polish).

Отто-Buczkowska E. 2002. Homeostaza gospodarki fosforanowo-wapniowej w populacji rozwojowej [Homeostasis of the phosphorus-calcium metabolism in the developing population]. Endokrynol. Diabetol., 8 (2): 105-110 (in Polish).

Papierkowskı A. 2002. Znaczenie magnezu w praktyce Iekarskiej. Cz. I. Przyczyny i objawy zaburzeñ gospodarki magnezowej [Role of magnesium in medical practice, Part I. causes and signs of disorders in magnesium balance]. Med. Rodz., 1: 31-34 (in Polish).

PARTYKa T., SitKowska-RYsiak E. 2001. Magnez - pierwiastek niezbêdny dla chorych operowanych [Magnesium - an essential element for operated patients]. Blok Operac., 4 (2): 5-7 (in Polish).

Pasternak K. 2000. Biopierwiastki w praktyce klinicznej [Bioelements in clinical practice]. Wyd. Folium, Lublin (in Polish).

Saris N.E., Marcela E., Karppanen H., Khawaj a J A., Lewenstam A. 2000. Magnesium. An update on physiological and analytical aspects. Clin. Chim. Acta, 294: 1-26.

SkIBNIEWSKa A.K., KowalsKı I.M., SiwıK P. 1999. Sk3adniki mineralne w diecie dzieci z mnogimi $z^{3}$ amaniami krêgos ${ }^{3} u p a$ [Mineral elements in a diet for children with multiple fractions of the spine]. Biul. Magnezol., 4 (2): 407- 411 (in Polish).

TAKAMI M., IKI M. 2005. Evidence-based, best practice guidelines for primary prevention of osteoporosis and osteoporotic fractures. Clin. Calcium, 15: 1312-1318.

Takami M., Shinnichi S. 2005. Bone and magnesium. Clin. Calcium, 15: 91-96.

Tomaszewskı J J . 2001. Diagnostyka laboratoryjna [Laboratory diagnostics]. PZWL, Warszawa (in Polish).

WALASEK L. 1998. Znaczenie niedoboru magnezu w praktyce klinicznej [Role of magnesium deficiency in clinical practice]. Czas. Aptekarskie, 5: 29-35 (in Polish).

Wolf F.I., CitTAdiNi A. 2003. Chemistry and biochemistry of magnesium. Mol. Aspects Med., 24: 3-9.

ZdRoj EWICZ Z., Belowska-Bieñ K. 2003. Receptor wapniowy - budowa i rola w gospodarce wapniowej [The calcium receptor - structure and role in calcium balance]. Prob. Ter. Monit., 14 (4): 186-191 (in Polish). 
